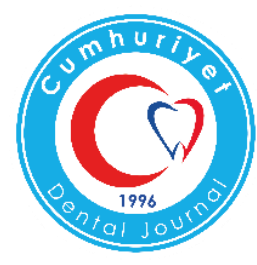

\section{RETROSPECTIVE EVALUATION OF SEDATION TECHNIQUES FOR TOOTH EXTRACTION IN PEDIATRIC PATIENTS}

\author{
Çocuk Hastalarda Diş Çekimi Amacıyla Uygulanan Sedasyon Tekniklerinin Geriye \\ Dönük Değerlendirilmesi
}

Dilek GÜNAY CANPOLAT ${ }^{1}$, Nükhet KÜTÜK ${ }^{2}$

Canay Y1lmaz ASAN ${ }^{2}$, Alper ALKAN ${ }^{2}$

\author{
Makale Kodu/Article Code : 400765 \\ Makale Gönderilme Tarihi $\quad$ :02.03.2018 \\ Kabul Tarihi
}

\begin{abstract}
Objective: Due to lack of past experiences and cooperation in anxious and fearful children, tooth extraction may be difficult to manage in dentistry. The aims of this retrospective study were to evaluate the various sedation techniques, complications and the characteristics of children whose tooth extraction were performed with deep sedation.
\end{abstract}

Materials and Methods: After approval by the Local Ethics Committee, a retrospective analysis was performed using the records of 885 patients who were treated with deep sedation for tooth extraction between the ages of 115 years for the period between 2012 and 2014The authors described the characteristics of the children, the sedation techniques used; and the complications.

Results: The mean weight of the patients was $20.09 \pm 7.3$ $\mathrm{kg}$ and the mean age was $5.72 \pm 2.5$ years. The mean duration of the operations was $16.14 \pm 5.4$ minutes. Propofol, ketamine, propofol-ketamine combination, alfentanil, midazolam, sevoflurane inhalation, sevoflurane inhalation + propofol were used for the anesthesia. There were no statistically significant differences among the anesthetic agents for post-operative complications ( $\mathrm{p}>0.05)$.

Conclusions: We concluded that propofol was a better option for deep sedation in pediatric dental extraction due to short duration time, rapid recovery and less nauseavomiting. Ketamine-propofol combination may be used as an alternative to propofol alone.

Keywords: children, sedation, tooth extraction
ÖZ

Amaç: Diş hekimi korkusu olan çocuklarda kooperasyon kurulamaması ve daha önce geçirilen diş tedavileri nedeni ile diş çekimi zordur. Bu çalışmanın amacı, derin sedasyon ile diş çekimi yapılan çocuklarda uygulanan farklı sedasyon tekniklerini ve komplikasyonlarını değerlendirmektir.

Gereç ve Yöntem: Erciyes Üniversitesi Lokal Etik Komitesinin onayı alındıktan sonra, 2012-2014 yılları arasında derin sedasyon ile diş çekimi yapılan, yaşları 1 ile 15 arasında 885 hastanın kaydı geriye dönük değerlendirildi. Çocuklara ait veriler, sedasyon teknikleri ve komplikasyonlar belirlendi.

Bulgular: Hastaların ortalama kilosu $20,09 \pm 7,3 \mathrm{~kg}$ ve ortalama yaşı $5,72 \pm 2,5$ iken, ortalama işlem süresi $16,14 \pm 5,4$ dakikayd. Anestezi amaciyla propofol, ketamin, propofol-ketamin kombinasyonu, alfentanil, midazolam, sevofluran inhalasyonu, sevofluran inhalasyonu+propofol kullanıld. Post operatif komplikasyonlar açısından anestezik ajanlar arasında istatistiksel olarak anlamlı bir fark bulunamadı $(p>0,05)$.

Sonuç: Sonuç olarak; işlem süresinin kısalığı, hızlı derlenme ve daha az bulantı-kusma gibi nedenlere bağlı olarak pediatrik dental işlemlerde, derin sedasyon amacıyla propofol daha etkili bir yöntemdir. Ketaminpropofol kombinasyonu, yalnız propofole alternatif bir yöntem olarak kullanılabilir.

Anahtar kelimeler: çocuklar, sedasyon, diş çekimi

\footnotetext{
${ }^{1}$ Department of Oral and Maxillofacial Surgery, Faculty of Dentistry, Erciyes University, Assistant Professor in Anesthesiology, Kayseri, Turkey

${ }^{2}$ Department of Oral and Maxillofacial Surgery, Faculty of Dentistry, Erciyes University, Kayseri, Turkey

${ }^{2}$ Department of Oral and Maxillofacial Surgery, Faculty of Dentistry, Bezmialem University, Professor, Kayseri, Turkey
} 


\section{INTRODUCTION}

Dental procedures are generally performed under local anesthesia. However, many fearful patients, especially children, are generally difficult to manage in dentistry due to lack of cooperation. ${ }^{1}$ Eradicating anxiety and avoiding possible psychological trauma in pediatric patients may prevent the development of dental phobia in children and behavior management problems when they become adults. Many behavioral management techniques are often suggested to solve the anxiety of children in dental offices. "Tell-show-do" is the most popular technique for this purpose., ${ }^{2,3}$ Nevertheless, these techniques may be insufficient; and conscious sedation or deep sedation, or general anesthesia may be considered as a sedation method to facilitate dental treatment. Numerous anesthetic techniques such as midazolam-sufentanyl and ketamine-midazolam combinations, oral midazolam, chloral hydrate and ketamine and propofol are used in pediatric dental treatment. $^{4,5}$

The Oral and Maxillofacial Surgery Clinic of our university provides comprehensive dental treatment for children under 18 years of age, and adults with special needs who require certain surgical techniques. Most of these patients are referred to this clinic from surrounding districts for dental treatments that must be performed with sedation or under general anesthesia. Although tooth extraction is commonly performed with local anesthesia in outpatient clinics in most children; for a minority of children, deep sedation may be required to perform this procedure.

The aims of this retrospective study were to evaluate the characteristics of children whose tooth extractions were performed with deep sedation, to discuss various sedation techniques used, and also to evaluate the complications observed after the application of these procedures in children in our clinic.

\section{MATERIAL AND METHODS}

The study protocol was approved by the Local Ethics Committee (2014/389). The research was designed as a descriptive study; and a retrospective analysis was performed using the hospital records of the patients. The study population was composed of pediatric patients who were admitted to our department between 2012-2014 and who were treated with deep sedation for tooth extraction. Inclusion criteria for the study were the absence of severe organ dysfunction, patients who had no contraindication to be treated under general anesthesia, and patients aged 1 to 15 years. The exclusion criteria were severe organ dysfunction, returning to general anesthesia because of the procedure being not performed with deep sedation, and patients who had an allergy to the drugs used.

All patients received an anesthetic assessment in the preoperative period and, when necessary, medical consultations related to their specific medical conditions with the relevant department were obtained. Administrative and clinical details, and the American Society of Anesthesiologists Physical Status Classification (ASA) status and medical conditions of the patients, age, gender, anesthetic agents used for deep sedation, routes of administration, indication for tooth extraction, the number of extracted teeth, duration of the operation, and complications were recorded. Informed consents were received from all parents before the procedure regarding the anesthesia techniques and the dental treatment to be performed.

All patients were pre-medicated using midazolam $0.05 \mathrm{mg} / \mathrm{kg}$ intravenously (IV), or $0.5 \mathrm{mg} / \mathrm{kg}$ orally in patients with difficult vascular access just before the procedure. The patients were taken into the operating room, and non-invasive standard monitoring was applied including assessments of heart rate (HR), peripheral oxygen saturation $\left(\mathrm{SpO}_{2}\right)$, and electrocardiography (ECG). Supplemental 
oxygen (3-4 L/min) was administered via a nasal mask. Patients were advised to fast for 46 hours before the procedure according to their age, and oral intake with liquids was allowed 2 hours after the procedure. The patients were discharged on the day of the operation if they did not need to be observed closely for their specific medical conditions. The residents of oral and maxillofacial surgery department performed all extractions.

Patients were divided into seven groups according to the type of the anesthetic agent used. The following drugs were administered to the patients: $1 \mathrm{mg} \mathrm{kg}^{-1}$ of propofol (IV) in Group $\mathrm{P}, 1 \mathrm{mg} \mathrm{kg}^{-1}$ of ketamine (IV) in Group K, $1 \mathrm{mg}$ $\mathrm{kg}^{-1}$ of ketamine and $1 \mathrm{mg} \mathrm{kg}^{-1}$ of propofol (IV) in Group KP, $0.1 \mathrm{mg} / \mathrm{kg}$ midazolam (IV) in Group M, $10 \mathrm{mcg} / \mathrm{kg}^{-1}$ alfentanil (IV) in Group A, 1-2\% sevoflurane: oxygen at a concentration of 50:50 in Group S, and 1-2\% sevoflurane: oxygen at a concentration of $50: 50+1 \mathrm{mg} \mathrm{kg}^{-1}$ of propofol (IV) in Group SP.

\section{STATISTICAL ANALYSIS}

Data were evaluated in the IBM SPSS 21.0 software program (IBM SPSS 21.0, Statistical Package for Social Sciences, Chicago, Illinois, the USA). Categorical variables were compared with the exact method of the Chi-Square test. A $\mathrm{p}<0.05$ value was considered significant.

\section{RESULTS}

Total 885 patient records were included in the study. The patients consisted of $372(42 \%)$ girls and 513 (58\%) boys. The mean age of the patients was $5.72 \pm 2.5$ years, with a range between the ages of 1 and 15 years. The mean weight of the patients was $20.09 \pm 7.3 \mathrm{~kg}$. Of the 885 cases, $802(90.6 \%)$ and $83(9.4 \%)$ belonged to ASA I and II, respectively. 2777 teeth were extracted and the mean number of the extracted teeth was $3.1 \pm 2.5$ $(p=0.466)$. The mean duration of the procedure was $16.14 \pm 5.4$ minutes. Detailed systemic disorders or medical conditions of the patients are given in Table 1.
Table 1. The systemic diseases of the patients

\begin{tabular}{|l|c|}
\hline The systemic diseases & Patients (n) \\
\hline Alegille & 1 \\
\hline ALL & 1 \\
\hline Anemia & 5 \\
\hline Apert Syndrome & 1 \\
\hline Asthma & 17 \\
\hline Renal Disease & 1 \\
\hline CP & 3 \\
\hline Down syndrome & 6 \\
\hline Epilepsy & 21 \\
\hline FMF & 1 \\
\hline Hydrocephaly & 1 \\
\hline Hyperactivity & 3 \\
\hline AuditiveDisfunction & 2 \\
\hline Cardiac Disfunction & 4 \\
\hline Cortical Atrophy & 1 \\
\hline Mental retardation & 6 \\
\hline Autism & 5 \\
\hline Talassamia & 1 \\
\hline TyroidDisfunction & 2 \\
\hline West Syndrome & 1 \\
\hline Total & $\mathbf{8 3}$ \\
\hline Values areexpressed as & \\
\hline
\end{tabular}

Values are expressed as $n$

The anesthetic agents used for sedation and the indications for tooth extraction are given in Table 2.

Table 2. The anesthetic agents used for sedation

Table 2. The anesthetic agents used for sedation
\begin{tabular}{|l|c|}
\hline The anesthetic agents & $\mathbf{\%}, \boldsymbol{n}$ \\
\hline Propofol & $82.3,728$ \\
\hline Ketamine & $1.1,10$ \\
\hline Midazolam & $0.3,3$ \\
\hline Alfentanil & $4.3,38$ \\
\hline Ketamine+propofol & $9.8,87$ \\
\hline Sevoflurane & $2.1,19$ \\
\hline The indications for tooth extraction & $\%, \mathbf{n}$ \\
\hline Dental decay & $95.7,847$ \\
\hline Dental abscess & $4.3,38$ \\
\hline Dental trauma & $1.7,15$ \\
\hline Supernumerary teeth & $1.5,13$ \\
\hline Values are expressed as \%, $n$ &
\end{tabular}


There were no statistically significant differences according to gender, indication for extraction, tooth number, trauma or supernumerary teeth between the groups ( $>0.05$ ). Nausea- vomiting was seen in a total of 54 patients $(6.1 \%)$ and sore throat was detected in 16 patients (1.8\%). Arrhythmia, bronchospasm or hypoxia were not seen in any of the patients. There were no statistically significant differences among the anesthetic agents in terms of nausea vomiting and sore throat ( $\mathrm{p}=0.09, \mathrm{p}=0.857$, Table 3 ).

Table 3. Number and percentage of patients who have postoperative complications

\begin{tabular}{|l|c|c|}
\hline Type of anesthetic agent & $\begin{array}{c}\text { Nausea and vomiting } \\
\boldsymbol{\%}, \boldsymbol{n}\end{array}$ & $\begin{array}{c}\text { Sore throat } \\
\boldsymbol{\%}, \mathbf{n}\end{array}$ \\
\hline Propopol & $5.1 \quad(\mathrm{n}=37)$ & $2.1 \quad(\mathrm{n}=15)$ \\
\hline Ketamine+propopol & $11.5 \quad(\mathrm{n}=10)$ & $0 \quad(\mathrm{n}=0)$ \\
\hline Alfentanil & $10.5 \quad(\mathrm{n}=4)$ & $2,6 \quad(\mathrm{n}=1)$ \\
\hline Ketamine & $20 \quad(\mathrm{n}=2)$ & - \\
\hline Inhalation & $6.3 \quad(\mathrm{n}=1)$ & - \\
\hline P values & $\mathbf{p = 0 . 0 9}$ & $\boldsymbol{p = 0 . 8 5 7}$ \\
\hline
\end{tabular}

Values are expressed as \%, n. P-values <0.05 were considered significant.

\section{DISCUSSION}

Dental anxiety may complicate dental treatment, especially in children. Managing anxious pediatric patients is one of the most commonly encountered challenges in dentistry. Most dental treatments can be performed with non-pharmacological behavioral therapies in pediatric patients. ${ }^{3}$ When these methods fail, conscious sedation through the administration of nitrous oxide inhalation can be an alternative method. Nitrous oxide inhalation provides successful results in pediatric patients with moderate anxiety levels; however, the success rate decreases with the severity of anxiety, leading to repeated procedures. ${ }^{6}$ Considering its low efficiency and the potential side effects of nitrous oxide, ${ }^{7}$ sedation with intravenous agents may be a suitable option for dental procedures such as tooth extraction in children. It has been reported that planned intravenous sedation prevents dental anxiety and provides a comfortable and safe operation without aggravating preoperative anxiety. ${ }^{8}$ It should be kept in mind that intravenous deep sedation requires monitoring, provisions for emergency conditions and close observation during and after the procedure to avoid the catastrophic results of anesthetic interventions. In our hospital, these procedures are performed in the operating room and maximal safety measures are taken.

Ketamine and propofol have been successfully applied to children for various operations. ${ }^{9}$ Propofol has a very rapid induction and recovery rate. Lebovic et al. ${ }^{10}$ reported that the recovery time of pediatric patients with cardiac catheterization is shorter with propofol compared to ketamine; and suggested it for daily operations as a more practical alternative. Therefore, propofol may be preferred for relatively short procedures. ${ }^{10}$ Dental treatments in which low doses of propofol are used have been shown to be effective in anxious children. ${ }^{1}$ Respiratory or cardiovascular depression and hypoxia may occur when propofol is not well titrated. When it is used alone, the rate of airway events may increase. ${ }^{8}$ In the present study, propofol was the most preferred anesthetic agent for intravenous sedation in tooth extraction. There were no airway events or hypoxemia $\left(\mathrm{SpO}_{2}<90 \%\right)$, which may have resulted from close observation of the patients because of the oral procedure, or emergency interventions with the jaw thrust maneuver when necessary, along with continued oxygen supplementation.

Ketamine is the most popular anesthetic agent for brief and painful procedures. 9 Ketamine usually maintains airway and respiratory function, and does not cause airway loss, oxygen desaturation or significant clinical emergency reactions. Although it has become a favorite in dental procedures, several adverse effects such as laryngospasm, transient respiratory depression, vomiting and psychomimetic effects such as recovery agitation or hallucinatory reactions have been 
documented. ${ }^{12,13}$ In this study, the incidence of nausea vomiting was higher in the $\mathrm{K}$ group than in the other groups. It was remarkable that the incidence of nausea-vomiting was higher in the $\mathrm{KP}$ group than the $\mathrm{P}$ group. Although these results were not statistically significant, they have clinical importance. When propofol was used in sub-anesthetic doses, less nauseavomiting was seen compared to ketamine alone. The antiemetic feature of propofol and the emetic effect of ketamine may have caused this result. Similarly, in a controlled study, upon procedural sedation, less vomiting was detected when a propofol-ketamine combination was used compared to when ketamine was used alone. $^{14}$

Guit et al. ${ }^{15}$ determined that propofol reduced the side effects of ketamine at subanesthetic doses, and a ketamine-propofol combination supplied hemodynamic stability. Also, the incidence of airway complications was reduced when propofol was combined with ketamine. ${ }^{9}$ However, Shah et al. ${ }^{14}$ reported similar efficiency and airway complications with ketamine alone or with a ketaminepropofol combination. In the present study, although the hemodynamic data were not evaluated in detail, no incidences of arrhythmia were observed in any patients as a complication. We did not encounter psychomimetic effects or hallucinations in any patient. This may be due to the preoperative midazolam administration before the patients were taken to the operating room.

Midazolam has a rapid onset of action and high metabolic clearance, and can produce hypnosis, amnesia and an anxiolytic effect when administered via the oral, intramuscular or intravenous route. Therefore, it has been used for premedication, anesthesia induction, maintenance or sedation for invasive procedures. ${ }^{16}$ Roelofse et al. ${ }^{4}$ reported that the usage of a combination of midazolam and ketamine or midazolam alone was a useful approach for dental treatments under local anesthesia. They recommended this technique for advanced airway management adequately when used. In another study, Wood ${ }^{17}$ used it successfully in the dental treatment of 500 children requiring dental sedation. In our retrospective study, we determined that we employed midazolam in only three patients. The adequate sedation levels in patients who were pre-medicated with midazolam preoperatively and who did not require an additional agent for the procedure caused this result. Thus, the tooth extraction procedure could be easily performed with midazolam without airway complications or nausea and vomiting.

Alfentanil, an opioid analgesic agent, has been used for tooth extraction or complete oral restorations under general anesthesia in pediatric patients. ${ }^{18,19}$ It may provide sedation and analgesia and may be related to a high rate of postoperative vomiting, as with all opioids. In our study, alfentanil was associated with a $10.5 \%$ incidence of nausea-vomiting, which was two-fold higher than with propofol.

Inhalation agents are also used as a sedation technique for dental treatment. Whereas nitrous oxide is widely used for dental sedation, it generally requires additional agents to maintain an adequate level of sedation. Sevoflurane is a more potent anesthetic agent than nitrous oxide; and has been used for conscious sedation in several dental procedures. $^{7}$ Kim et al. ${ }^{20}$ suggested that sevoflurane might be an alternative sedating agent in the pediatric dental outpatient setting. In the present study, sevoflurane was employed in patients in whom an intravenous approach could not be used due to procedural difficulty. Only three patients required additional propofol intravenously. Nausea and vomiting occurred in only one of the patients whose tooth extraction was performed under sevoflurane anesthesia.

Sore throat is a complication that is commonly caused by endotracheal intubation, dry airway gases or airway suction. ${ }^{21}$ In this study, although none of the patients were 
intubated and no supraglottic airway devices were used, sore throat was observed at a low incidence. We believe that sore throat was most likely to have been caused by airway suction, which was used to provide better visualization and to remove blood and secretions.

In conclusion, propofol was the most preferred anesthetic agent for deep sedation for pediatric dental extractions due to its rapid onset, recovery and low incidence of nausea and vomiting. The ketamine-propofol combination may be a good alternative as it provides better analgesia. However, the ideal anesthetic agent should be chosen according to the medical condition of the patient.

Acknowledgements: We thank Dr. Ferhan Elmal1 for his excellent assistance on the statistical analyses and Dr Mustafa Denizhan Y1ldirım for his contributions on this study. There is no funding for this study.

Conflict of Interest: Authors have no conflict of interest.

\section{REFERENCES}

1. Giovannitti JA Jr. Dental anesthesia and pediatric dentistry. Anesth Prog. 1995;42:9599.

2. Klingberg G, Vannas Löfqvist L, Bjarnason $\mathrm{S}$, Norén JG. Dental behavior management problems in Swedish children. Community Dent Oral Epidemiol. 1994;22:201-205.

3. Farhat-McHayleh N, Harfouche A, Souaid P. Techniques for managing behaviour in pediatric dentistry: comparative study of live modelling and tell-show-do based on children's heart rates during treatment. J Can Dent Assoc. 2009;75:283.

4. Roelofse JA, Joubert JJ, Roelofse PG. A double-blind randomized comparison of midazolam alone and midazolam combined with ketamine for sedation of pediatric dental patients. J Oral Maxillofac Surg. 1996;54:838844
5. Lourenço-Matharu L, Ashley PF, Furness S. Sedation of children undergoing dental treatment. Cochrane Database Syst Rev. 2012; 14:CD003877.

6. Major E, Winder M, Brook AH, Berman DS. An evaluation of nitrous oxide in the dental treatment of anxious children. A physiological and clinical study. Br Dent J. 1981;151:186191.

7. Becker DE, Rosenberg M. Nitrous oxide and the inhalation anesthetics. Anesth Prog. 2008;55:124-130

8. Seto M, Sakamoto Y, Takahashi H, Kita R, Kikuta T. Does planned intravenous sedation affect preoperative anxiety in patients? Int J Oral Maxillofac Surg. 2013;42:497-501.

9. Alletag MJ, Auerbach MA, Baum CR. Ketamine, propofol, and ketofol use for pediatric sedation. Pediatr Emerg Care. 2012;28:1391-1395

10.Lebovic S, Reich DL, Steinberg LG, Vela FP, Silvay G. Comparison of propofol versus ketamine for anesthesia in pediatric patients undergoing cardiac catheterization. Anesth Analg. 1992;74:490-494.

11.Hosey MT, Makin A, Jones RM, Gilchrist F, Carruthers M. Propofol intravenous conscious sedation for anxious children in a specialist paediatric dentistry unit. Int $\mathbf{J}$ Paediatr Dent. 2004;14:2-8.

12.Bredmose PP, Grier G, Davies GE, Lockey DJ. Pre-hospital use of ketamine in paediatric trauma. Acta Anaesthesiol Scand. 2009;53:543545.

13.Green SM, Roback MG, Kennedy RM, Krauss B. Clinical practice guideline for emergency department ketamine dissociative sedation: 2011 update. Ann Emerg Med. 2011;57:449-461.

14. Shah A, Mosdossy G, McLeod S, Lehnhardt K, Peddle M, Rieder M. A blinded, randomized controlled trial to evaluate ketamine/propofol 
versus ketamine alone for procedural sedation in children. Ann Emerg Med. 2011;57:425-433

15. Guit JB, Koning HM, Coster ML, Niemeijer RP, Mackie DP. Ketamine as analgesic for total intravenous anaesthesia with propofol. Anaesthesia. 1991;46:24-27.

16. Reves JG, Fragen RJ, Vinik HR, Greenblatt DJ. Midazolam: pharmacology and uses. Anesthesiology. 1985;62:310-324.

17. Wood M. The use of intravenous midazolam and ketamine in paediatric dental sedation. SAAD Dig. 2013;29:18-30.

18.Burtles R. Alfentanil with methohexitone in paediatric dental anaesthesia. J Dent. 1991;19:192-194

19.Davis PJ, Chopyk JB, Nazif M, Cook DR. Continuous alfentanil infusion in pediatric patients undergoing general anesthesia for complete oral restoration. J Clin Anesth. 1991;3:125-130.
20.Kim SO, Kim YJ, Hyun HK, Koo YS, Shin TJ. Deep sedation with sevoflurane inhalation via a nasal hood for brief dental procedures in pediatric patients. Pediatr Emerg Care. 2013;29:926-928

21.Higgins PP, Chung F, Mezei G. Postoperative sore throat after ambulatory surgery. Br J Anaesth. 2002;88:582-584.

\section{Corresponding Author}

Canay Y1lmaz Asan

Erciyes University,

Faculty of Dentistry

Department of Maxillofacial Surgery

Talas Kayseri / TURKEY

Telephone: +90 3522076666 - 29183

Facsimile: +903524380657

E-mail: dtcanayasan@gmail.com 